\title{
Blackberry pomace microspheres: An approach on anthocyanin degradation
}

\author{
Microesferas de bagaço de amora-preta: Uma abordagem sobre a \\ degradação de antocianina
}

\author{
Suelen Siqueira dos Santos ${ }^{1 *}$ (D) Carolina Moser Paraíso ${ }^{1}$ (D) Grasiele Scaramal Madrona ${ }^{2}$ (D)
}

'Universidade Estadual de Maringá/UEM, Maringá, PR, Brasil

¿Universidade Estadual de Maringá/UEM, Departamento de Engenharia de Alimentos, Maringá, PR, Brasil

*Corresponding author: suelensiqueira.eng@gmail.com

Received in May 25, 2020 and approved September 21, 2020

\begin{abstract}
Blackberry pomace is a rich source of antioxidant compounds, including anthocyanins, but these compounds degrade easily in the presence of high temperatures. Therefore, the present study aimed to evaluate the effect of temperature on anthocyanin degradation in spray-dried blackberry pomace extract. Maltodextrin was used as a drying aid agent in a spray drying process to produce microspheres. The experiment was set up at Maringá-PR, Brazil ( $23^{\circ} 25^{\prime} 31^{\prime \prime} \mathrm{S}, 51^{\circ} 56^{\prime} 19^{\prime \prime} \mathrm{W}, 596 \mathrm{~m}$ altitude). The thermal stability of anthocyanins was evaluated in the presence and absence of copigments at different temperatures ranging from $70^{\circ} \mathrm{C}$ to $100^{\circ} \mathrm{C}$ using degradation kinetics. The role of maltodextrin in protecting anthocyanins during the spray drying process was studied at high temperatures. The highest anthocyanin stability was found at $70^{\circ} \mathrm{C}$. We also studied the effect of copigment phytic acid on the stability of anthocyanin and found that the copigment plays an important role in anthocyanin protection at high temperatures. The spray drying process with maltodextrin is a feasible technique for the preservation of food products and can improve anthocyanin's thermal stability. The reuse of industrial wastes, such as blackberry pomace along with preservation techniques, can be a good strategy to reduce their negative impact on the environment.
\end{abstract}

Index terms: Rubus fruticosus; antioxidant analyses; spray dryer; kinetics.

\begin{abstract}
RESUMO
O bagaço de amora-preta é uma fonte rica em compostos antioxidantes, incluindo antocianinas, compostos se degradam facilmente na presença de altas temperaturas. Portanto, o presente estudo teve como objetivo avaliar o efeito da temperatura na degradação de antocianinas em extrato de bagaço de amora-preta seco por spray-dryer. A maltodextrina foi usada como agente auxiliar de secagem em um processo de secagem por pulverização para produzir microesferas. O experimento foi instalado em Maringá-PR, Brasil (23 25 '31 “S, 51 56' 19" W, 596 m de altitude). A estabilidade térmica das antocianinas foi avaliada na presença e ausência de copigmentos em diferentes temperaturas variando de $70{ }^{\circ} \mathrm{C}$ a $100{ }^{\circ} \mathrm{C}$ usando cinética de degradação. O papel da maltodextrina na proteção das antocianinas durante o processo de secagem por spray dryer foi estudado em altas temperaturas. A maior estabilidade de antocianina foi encontrada a $70{ }^{\circ} \mathrm{C}$. Também estudamos o efeito do copigmento ácido fítico sobre a estabilidade da antocianina e observamos que o copigmento desempenha um papel importante na proteção antocianina em altas temperaturas. O processo de secagem por spray dryer com maltodextrina é uma técnica viável para a preservação de produtos alimentícios e pode melhorar a estabilidade térmica das antocianinas. O reaproveitamento de resíduos industriais, como o bagaço de amora, junto com técnicas de preservação, pode ser uma boa estratégia para reduzir seus impactos negativos ao meio ambiente.
\end{abstract}

Termos para indexação: Rubus fruticosus; análises antioxidantes; spray dryer; cinética.

\section{INTRODUCTION}

Fruit and vegetable residues have been recognized as a rich source of bioactive compounds. Thus, the use of agro-industrial residues such as blackberry pomace can be feasible for the development of functional foods. Several studies have highlighted that fruit processing produces about $20 \%$ to $60 \%$ of byproducts such as peels, seeds, stems, and pulp that can be used to extract bioactive compounds (Machado et al., 2018).

The research on the blackberry (Rubus fruticosus) composition has revealed that the typical red color of the fruit is because of anthocyanins, mainly, including cyanidin-3-O-glucoside and cyanidin-3-O-rutinoside. Besides anthocyanins, the fruit also contains flavonoids, 
phenolic acids, and ellagitannins (Machado et al., 2018; Lee; Durst; Wrolstad, 2005).

Some studies have shown that anthocyanins are less stable at a high temperature. Heat treatment is a common method for food preservation, but its usage can negatively affect the stability of anthocyanins. Therefore, the study of an alternative technique that can increase anthocyanin stability would be significant. Thermal degradation of anthocyanins results in their color loss and appearance of brown compounds, possibly because of chalcone formation followed by loss of glycosyl moieties and formation of $\alpha$-diketone compounds (Maciel et al., 2018; Pedro; Granato; Rosso, 2016; Reyes; Cisneros-Zevallos, 2007). The flavylium nucleus of anthocyanins can provide a number of colors because of its interaction with copigments existing in an aqueous medium. Van der Waals forces and hydrophobic interactions result in a strong association between the anthocyanin molecules and copigment (Maciel et al., 2018; Pedro; Granato; Rosso, 2016; Grajeda-Iglesias et al., 2016).

The use of maltodextrin as a drying aid agent can be used to increase the stability of bioactive compounds when applied to food products (Rezende; Nogueira; Narain, 2018; Ye; Georges; Selomulya, 2018). A spray drying technique can improve the shelf-life of food and food ingredients. The technique is commonly used in the food industry because of its simplicity, flexibility, and economical feasibility, along with its application in drying bioactive compounds. The technique transforms a liquid solution, suspension, or emulsion into a dried particle (Lisboa; Duarte; Cavalcanti-Mata, 2018; Ramos et al., 2019; Salminen et al., 2019).

The objective of this study was to produce and characterize microspheres from blackberry pomace extract, and evaluate the effect of storage (or processing) temperature on anthocyanin degradation.

\section{MATERIAL AND METHODS}

\section{Materials}

Blackberry (Rubus fruticosus) pomace was purchased from the producer of Paraibuna-SP, Brazil (23 $23^{\prime} 10^{\prime \prime} \mathrm{S}, 45^{\circ} 39^{\prime} 44^{\prime \prime} \mathrm{W}, 635 \mathrm{~m}$ altitude) from a single batch and was frozen $\left(-18{ }^{\circ} \mathrm{C}\right)$ until use. Maltodextrin (M) DE10 was provided by Cargil ${ }^{\circledR}$ (Campinas-SP). Other reagents were of analytical grade and purchased from Sigma Aldrich ${ }^{\circledR}$.
Samples preparation and encapsulation of bioactive compounds

The experiment was set up at Maringá-PR, Brazil ( $23^{\circ} 25^{\prime} 31^{\prime \prime} \mathrm{S}, 51^{\circ} 56^{\prime} 19^{\prime \prime} \mathrm{W}, 596 \mathrm{~m}$ altitude).

Initially, the blackberry pomace (BP) was defrosted. Considering the results of a preliminary experiment, the $\mathrm{BP}$ was diluted with water up to the concentration of 500 $\mathrm{mg} \mathrm{mL} \mathrm{m}^{-1}$. Bioactive compounds were extracted using an ultrasonic cleaner bath (Ultracleaner 1650 Unique, 40 $\mathrm{kHz}$ frequency, 120 Watts RMS power) for $45 \mathrm{~min}$ at the temperature-controlled manually at around $60 \pm 3{ }^{\circ} \mathrm{C}$. The variation was controlled by considering the increase in temperature caused by the ultrasound treatment (Santos et al., 2017a) The solution was filtered subsequently to obtain the blackberry pomace extract (BE).

The blackberry microspheres (BM) were prepared using maltodextrin (DE 10) as a drying aid agent. Maltodextrin was directly mixed with the extract in the ratio of $1: 1(\mathrm{w} / \mathrm{w})$, by using mechanical agitation. The samples of BE and BM were dried in a spray dryer using the following conditions: Inlet drying air temperature $150^{\circ} \mathrm{C}$ and outlet $110^{\circ} \mathrm{C}$, atomization pressure 0.08 to 0.14 bar, average drying airflow $3.5 \mathrm{~m}^{3} \mathrm{~h}^{-1}$, average feed rate $0.3 \mathrm{~L} \mathrm{~h}^{-1}$ in the LM-MSD 1.0 Mini Spray-dryer equipment (Santos et al., 2017a). The sample BP was frozen for $48 \mathrm{~h}$ at $-10{ }^{\circ} \mathrm{C}$ and subsequently submitted to freeze-drying for two days to ensure complete drying (freeze L108, Liobras).

The dried samples of BP, BE, and BM were stored in plastic containers and kept frozen $\left(-18^{\circ} \mathrm{C}\right)$ for further analysis.

\section{Effect of temperature on copigmentation}

The effect of temperature on anthocyanin stability was evaluated for $\mathrm{BE}$ and $\mathrm{BM}$ samples in the presence and absence of copigments. Anthocyanin stability in the presence of copigment was evaluated using citrate buffer (pH 3.0) and copigment phytic acid (4.0 x 10-4 $\left.\mathrm{mol} \mathrm{L}^{-1}\right)$, whereas anthocyanin stability in the absence of copigment (control) was evaluated using only citrate buffer ( $\mathrm{pH} 3.0$ ) (Maciel et al., 2018).

The solutions of $\mathrm{BE}$ and $\mathrm{BM}$ with and without phytic acid were kept into a thermostatic bath (sensor PT100 Nova Orgânica) at $70{ }^{\circ} \mathrm{C}, 80^{\circ} \mathrm{C}, 90^{\circ} \mathrm{C}$, and $100^{\circ} \mathrm{C}$. The absorbance was recorded using a spectrophotometer at $513 \mathrm{~nm}$ at intervals of $30 \mathrm{~min}$. Using the data, kinetic parameters such as rate constant $(\mathrm{k})$ and half life time $\left(\mathrm{t}_{1 / 2}\right)$ were mathematically calculated using Equations 1 and 2, respectively (Pedro; Granato; Rosso 2016).

$\ln \left(A_{t}\right) / A_{0}=-k x t$ 
$\mathrm{t}_{1 / 2}=\ln 2 / \mathrm{k}$

Total phenolic compounds (TPC), total monomeric anthocyanins (TMA), and total flavonoids (TF)

Total phenolic compounds (TPC) analysis was carried out by using a reaction between Folin-Ciocalteu, sodium carbonate $\left(\mathrm{Na}_{2} \mathrm{CO}_{3}\right)$, and sample. The reaction mixture was incubated for $30 \mathrm{~min}$ at $25{ }^{\circ} \mathrm{C}$, and the absorbance was measured using a spectrophotometer at $725 \mathrm{~nm}$ (Pierpoint, 2004). Results were expressed as $\mu \mathrm{g}$ of gallic acid equivalent (GAE) per mg of dry matter.

Total monomeric anthocyanins (TMA) were determined using the differential $\mathrm{pH}$ method using reagents potassium chloride $(\mathrm{KCl})$ and sodium acetate $\left(\mathrm{C}_{2} \mathrm{H}_{3} \mathrm{NaO}_{2}\right)$. The reaction mixture was incubated for 20 min at $25^{\circ} \mathrm{C}$, and the absorbance was measured using a spectrophotometer at 520 and $700 \mathrm{~nm}$ (Lee, Durst, and Wrolstad 2005). The results were expressed in $\mu \mathrm{g}$ of cyanidin-3-glucoside per mg of dry matter.

Total flavonoids (TF) analysis was performed using aluminum chloride $\left(\mathrm{AlCl}_{3}\right)$, sodium nitrite $\left(\mathrm{NaNO}_{2}\right)$, and sodium hydroxide $(\mathrm{NaOH})$. The absorbance of the reaction mixture was measured immediately using a spectrophotometer at $510 \mathrm{~nm}$ (Alothman; Bhat; Karim, 2009). Results were expressed in $\mu \mathrm{g}$ of quercetin equivalent $(\mathrm{QE})$ per mg of dry matter.

\section{Antioxidant activity analysis}

Reduction in the stable DPPH radicals concentration was measured by a spectrophotometric assay by using the stable radical DPPH (2, 2-diphenyl1 -picrylhydrazyl) reagent. The reaction mixture was incubated for $1 \mathrm{~h}$ at $25^{\circ} \mathrm{C}$ and absorbance was measured using a spectrophotometer at $515 \mathrm{~nm}$ (Thaipong et al., 2006).

Antioxidant activity was measured using the ABTS method with the help of the colorimetric assay. Reagents such as ABTS (2, 2'-AZINO-BIS (3-ethylbenzo-thiazoline-6-sulfonic acid) diammonium salt and potassium persulfate $\left(\mathrm{K}_{2} \mathrm{~S}_{2} \mathrm{O}_{8}\right)$ were used for the reaction, and absorbance was measured using a spectrophotometer at $734 \mathrm{~nm}$ after $6 \mathrm{~min}$ of incubation at $25^{\circ} \mathrm{C}$ (Nenadis et al., 2004).

Antioxidant activity was measured using the FRAP method by mixing the sample directly with distilled water and FRAP (Ferric Reducing Antioxidant Potential) reagent. The reaction mixture was maintained at $37^{\circ} \mathrm{C}$ in a water bath for $30 \mathrm{~min}$. The absorbance was measured using a spectrophotometer at $595 \mathrm{~nm}$ (Pulido; Bravo; Saura-Calixto 2000).
Results of all antioxidant analyses were expressed in $\mu \mathrm{M}$ of Trolox equivalent (TE) per mg of dry matter.

\section{Colorimetric analysis}

Colorimetric analysis of the samples was performed by using the portable Minolta ${ }^{\circledR}$ CR400 colorimeter. The system used was CIELAB $\left(\mathrm{L}^{*}, \mathrm{a}^{*}, \mathrm{~b}^{*}, \mathrm{C}+\right.$ and $\left.\mathrm{H}^{\circ}\right)$.

\section{Morphological characterization by scanning electron microscopy (SEM)}

The particle morphology of microspheres was characterized using a scanning electron microscope (JEOL model JSM-6060 LV). Metal support with a double-sided tape of carbon was used to fix the samples, which was covered with gold. The samples were visualized with the magnification of 250 to 10000 times using the excitation voltage of $12.5 \mathrm{kV}$.

\section{Statistical analysis}

All readings were subjected to statistical analysis using the analysis of variance and Tukey's test with the $\mathrm{p}$-value of $<0.05$. Statistical analyses were performed using the statistical program Sisvar 5.6. Calibration curves for the antioxidant analyses were plotted in the Graph Pad Prism 5 software.

\section{RESULTS AND DISCUSSION}

\section{Antioxidant and color analyses}

Table 1 shows the analyses of TPC, TMA, antioxidant, and color of BP, BE, and BM samples.

The values of TPC, TMA, TF, DPPH, ABTS, and FRAP were higher for sample BE compared to sample BP, corroborating with other similar studies (Santos et al., 2017a; Rodrigues et al., 2018). This could be due to the high temperatures used in the spray dryer, which can improve the antioxidant activity of samples by the formation of phenolic compounds resulting from the Maillard reaction, which generally exhibit high antioxidant properties (Murador et al., 2018; Pitalua et al., 2010).

A comparison between TMA values of samples $\mathrm{BM}$ and BE (Table 1) showed that maltodextrin protected anthocyanins during the drying process. Both samples showed similar values since the BM sample represented only $50 \%$ of the BE. BM sample, as expected, showed around $50 \%$ of the values for TPC, TF, DPPH, ABTS, and FRAP analyses compared to BE. Also, the spray drying technique had a great impact on encapsulation characteristics, including stability (Santos et al., 2019; Santos et al., 2017b). 
Table 1: Analyses of TPC, TMA, antioxidant, and color of BP, BE, and BM samples.

\begin{tabular}{|c|c|c|c|}
\hline & $\mathrm{BP}$ & $\mathrm{BE}$ & $\mathrm{BM}$ \\
\hline $\mathrm{TPC}$ & $5.43^{c} \pm 0.73$ & $54.08^{a} \pm 6.43$ & $27.67^{b} \pm 2.91$ \\
\hline TMA" & $0.46^{b} \pm 0.07$ & $2.52^{\mathrm{a}} \pm 0.12$ & $2.50^{a} \pm 0.05$ \\
\hline TF"II & $18.02^{\mathrm{c}} \pm 2.34$ & $178.47^{a} \pm 27.42$ & $85.48^{b} \pm 5.11$ \\
\hline $\mathrm{DPPH}^{\mathrm{IV}}$ & $2.27^{c} \pm 0.36$ & $22.44^{a} \pm 0.72$ & $11.41^{b} \pm 1.98$ \\
\hline ABTSV & $36.70^{c} \pm 2.16$ & $600.50^{a} \pm 8.13$ & $246.90^{b} \pm 5.13$ \\
\hline FRAPVI & $150.69^{c} \pm 3.45$ & $1773.16^{\mathrm{a}} \pm 48.07$ & $759.42^{b} \pm 30.60$ \\
\hline$L^{*}$ & $26.29^{b} \pm 1.84$ & $16.46^{c} \pm 1.75$ & $41.77^{a} \pm 4.06$ \\
\hline$a^{*}$ & $24.70^{b} \pm 0.98$ & $26.91^{\mathrm{b}} \pm 1.74$ & $43.10^{a} \pm 0.87$ \\
\hline$b^{*}$ & $12.25^{b} \pm 0.56$ & $11.21^{c} \pm 0.36$ & $15.01^{\mathrm{a}} \pm 0.01$ \\
\hline C & $27.58^{b} \pm 1.11$ & $28.54^{b} \pm 0.72$ & $45.65^{a} \pm 0.83$ \\
\hline$H^{\circ}$ & $26.55^{a} \pm 0.29$ & $23.14^{\mathrm{b}} \pm 0.46$ & $19.24^{c} \pm 0.30$ \\
\hline
\end{tabular}

Means followed by the same letters on line did not differ among themselves by Tukey's test ( $p<0.05)$. BP: blackberry pomace; BE: blackberry pomace extract (100\% extract); BM: blackberry pomace microsphere (50\% maltodextrin + $50 \%$ extract); ' $\mu \mathrm{g}$ GAE. $\mathrm{mg}^{-1}$ of dry matter; "$\mu \mathrm{g}$ cyanidin-3-glucoside. $\mathrm{mg}^{-1}$ of dry matter; "I $\mu \mathrm{g}$ EQ.mg-1 of dry matter; ${ }^{\mathrm{Iv}, \mathrm{v}}$ and ${ }^{\mathrm{V}} \mu \mathrm{M}$ TE.mg-1 of dry matter. TPC: total phenolic compounds; TMA: total monomeric anthocyanins; TF: total flavonoids.

Moreover, the present study reported higher TMA and TPC values of microspheres than those reported by other studies on microcapsules of blackberry pomace. One study reported $1.18 \mu \mathrm{g}$ cyanidin-3-glucoside $\mathrm{mg}^{-1}$ for TMA and $23.13 \mu \mathrm{g} \mathrm{GAE} \mathrm{mg}^{-1}$ for TPC (Santos et al., 2017b). Another study has reported $1.66 \mu \mathrm{g}$ cyanidin-3-glucoside $\mathrm{mg}^{-1}$ for TMA (Santos et al., 2019).

A comparison between the colorimetric values of BM and BE samples showed an increase in the value of $\mathrm{L}^{*}$. Probably because of the use of maltodextrin, the colorimetric intensity of the BM sample was lower than that of BE. A similar trend was observed for chromaticity (C). The $\mathrm{C}$-value is the relative strength of any given color; the higher the $\mathrm{C}$, greater is the saturation of colors that are perceptible to humans (Cuadros et al., 2020).

The value of $\mathrm{a}^{*}$ (red intensity) for the BM sample was higher than that of the BE sample, indicating that maltodextrin encapsulation protected the coloring compounds in the sample during the drying process. The parameter $\mathrm{H}^{\circ}$ is an angle specifying the hue of a color and is considered as the qualitative attribute of the color, which traditionally defines as reddish, greenish, etc. Graphically, $0^{\circ}$ is attributed to red, $90^{\circ}$ to yellow, $180^{\circ}$ to green, and $270^{\circ}$ to blue (Cuadros et al., 2020). Thus, the $\mathrm{H}^{\circ}$ angle of sample BM (Table 1) was lower than that of sample BP and $\mathrm{BE}$, indicating its proximity to red.

Other similar studies have reported lower values for parameters $\mathrm{L}^{*}, \mathrm{a}^{*}, \mathrm{~b}^{*}, \mathrm{C}$, and $\mathrm{H}^{\circ}$ than the present study, probably because of ultrasound-assisted extraction that provided color compounds in high concentration (Ferrari et al., 2012; Santos et al., 2017a).

\section{Morphological characterization by scanning electron microscopy (SEM)}

Figure 1 shows the morphologies of blackberry pomace samples characterized by a scanning electron microscopy.

BP samples dried by lyophilization (Figures 1A and 1B) showed morphology similar to broken glass. They were in the form of amorphous particles of different sizes with porosity due to the structural rigidity, characteristic of this drying technique (Ezhilarasi et al., 2013; Kuck; Noreña, 2016).

On the other hand, BE samples (Figures 1C and 1D) showed amorphous nature and irregular shape compared to the BM samples (Figures $1 \mathrm{E}$ and $1 \mathrm{~F}$ ). Microspheres showed circular morphology with different sizes are characteristic of this drying method, and were similar to roughness and cracking formed by fast evaporation of water (Ferrari et al., 2012; Medina-Torres et al., 2016).

\section{Effect of temperature in the presence and absence of copigment}

Table 2 and Figure 2 show the effect of temperature and kinetic parameters involved in the stability of samples $\mathrm{BE}$ and $\mathrm{BM}$ in the absence and presence of 
copigments. It was observed that the degradation of anthocyanins in samples BE and BM increased with an increase in the heating temperature and time. This linear relationship between the logarithm of the concentration of anthocyanins and time indicates the first-order kinetics for anthocyanin degradation (Sinela et al., 2017).
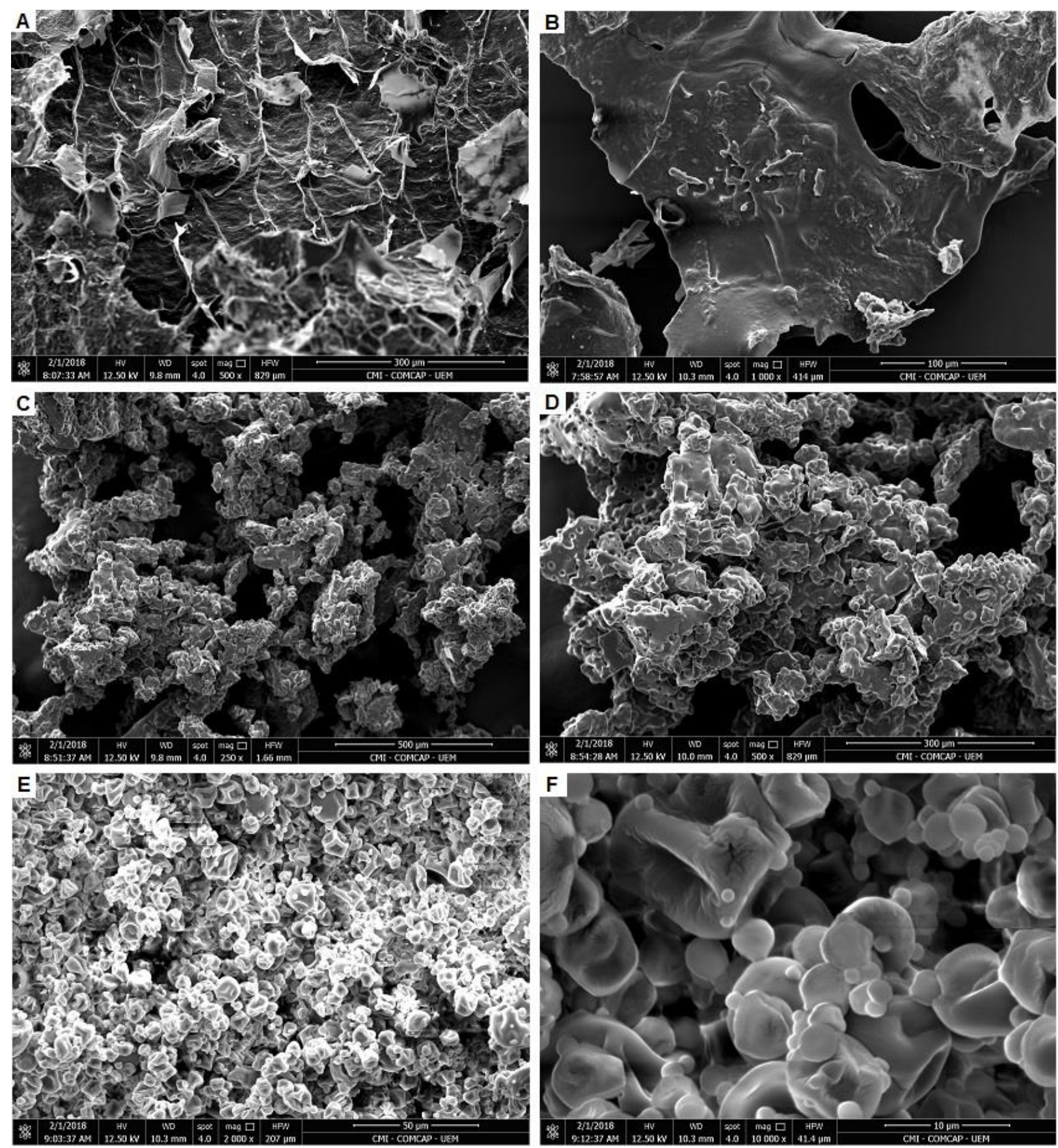

Figure 1: Samples (A) BP: blackberry pomace with an increase of 500x and (B) 1000x; (C) BE: blackberry pomace extract with an increase of 250x and (D) 500x; (E) BM: blackberry pomace microsphere with an increase of 2000x and (F) 10000x. 
Table 2: Kinetic parameters of the effect of temperature on the stability of BE and BM in the absence and presence of copigments.

\begin{tabular}{|c|c|c|c|c|}
\hline Temperature $\left({ }^{\circ} \mathrm{C}\right)$ & $t_{1 / 2}(h)$ & $\mathrm{k}\left(\mathrm{min}^{-1}\right)$ & $t_{1 / 2}(h)$ & $\mathrm{k}\left(\mathrm{min}^{-1}\right)$ \\
\hline & \multicolumn{2}{|c|}{ Blackberry extract (BE) } & \multicolumn{2}{|c|}{ Blackberry microsphere (BM) } \\
\hline \multicolumn{5}{|l|}{ Control } \\
\hline 70 & 12.27 & $9.42 \times 10^{-4}(0.8809)$ & 16.57 & $6.97 \times 10^{-4}(0.8235)$ \\
\hline 80 & 7.72 & $1.50 \times 10^{-3}(0.9388)$ & 8.20 & $1,41 \times 10^{-3}(0.9156)$ \\
\hline 90 & 3.86 & $2.99 \times 10^{-3}(0.9831)$ & 4.39 & $2.63 \times 10^{-3}(0.9643)$ \\
\hline 100 & 1.85 & $6.23 \times 10^{-3}(0.9864)$ & 1.90 & $6.07 \times 10^{-3}(0.9820)$ \\
\hline \multicolumn{5}{|l|}{ Phytic acid } \\
\hline 70 & 12.42 & $9.30 \times 10^{-4}(0.8458)$ & 16.94 & $6.82 \times 10^{-4}(0.8025)$ \\
\hline 80 & 7.91 & $1.46 \times 10^{-3}(0.9340)$ & 8.65 & $1.34 \times 10^{-3}(0.9000)$ \\
\hline 90 & 4.19 & $2.76 \times 10^{-3}(0.9880)$ & 4.50 & $2.57 \times 10^{-3}(0.9717)$ \\
\hline 100 & 2.21 & $5.23 \times 10^{-3}(0.9805)$ & 2.33 & $4.95 \times 10^{-3}(0.9832)$ \\
\hline
\end{tabular}

$\mathrm{t}_{1 / 2}$ : half-time life; $\mathrm{k}$ : rate constant of anthocyanins degradation; Coefficient of determination $\left(\mathrm{R}^{2}\right)$ shown in parentheses.

a) Control (BE)

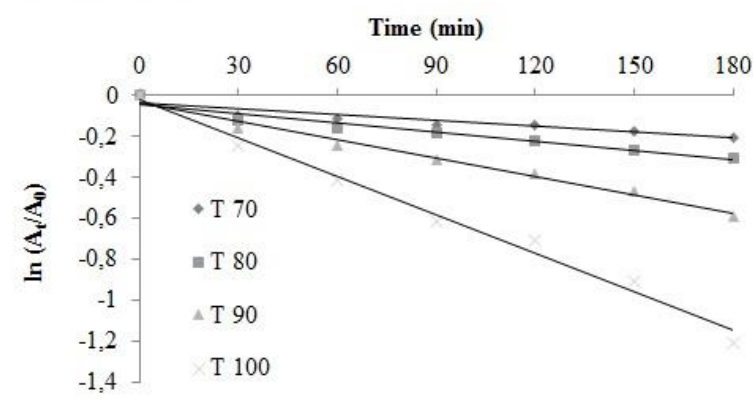

c) Control (BM)

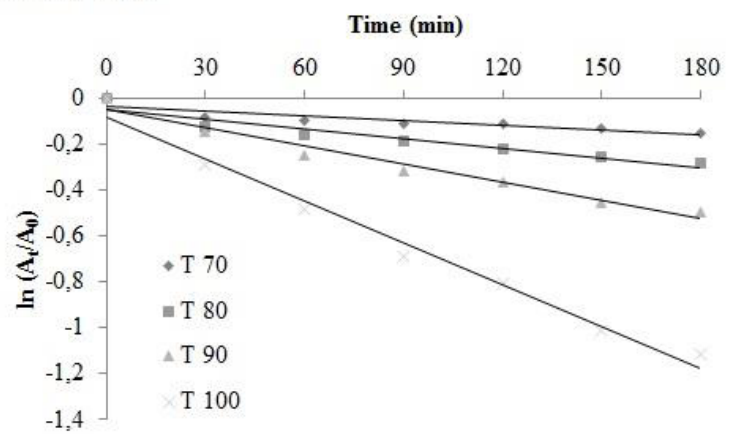

b) Phytic acid (BE)

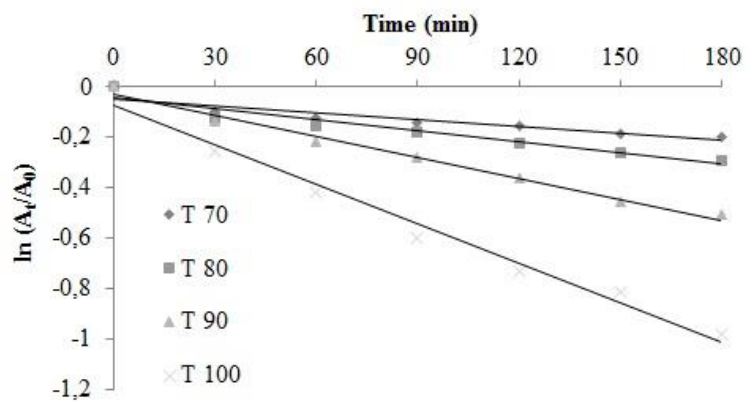

d) Phytic acid (BM)

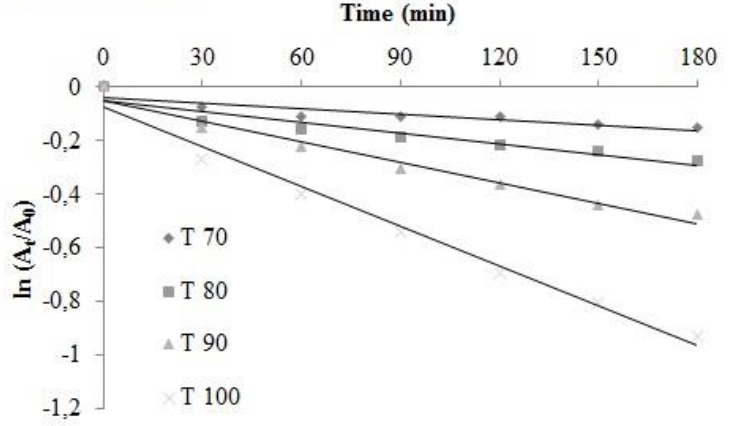

Figure 2: Degradation kinetics of anthocyanins; (a) Control BE: blackberry extract; (b) Phytic acid BE: blackberry extract; (c) Control BM: blackberry microsphere; (d) Phytic acid BM: blackberry microsphere.

The highest half-life time (Table 2) was found at $70{ }^{\circ} \mathrm{C}$, and $\mathrm{t}_{1 / 2}$ for $\mathrm{BE}$ control and $\mathrm{BE}$ copigment were 12.27 and $12.42 \mathrm{~h}$, respectively. On the other hand, $\mathrm{t}_{1 / 2}$ for
$\mathrm{BM}$ control and BM copigment were 16.57 and $16.94 \mathrm{~h}$, respectively, indicating the highest levels of anthocyanins' thermal stability at this temperature. 
The use of phytic acid as a copigment provided a reduction in the rate of anthocyanins degradation, which was less evident at $70{ }^{\circ} \mathrm{C}$. According to Table 2, $\mathrm{t}_{1 / 2}$ for copigment BE sample increased by $1.22 \%$ at $70^{\circ} \mathrm{C}$, $2.46 \%$ at $80{ }^{\circ} \mathrm{C}, 8.55 \%$ at $90{ }^{\circ} \mathrm{C}$, and $19.46 \%$ at $100{ }^{\circ} \mathrm{C}$ compared to the control BE sample. Moreover, $\mathrm{t}_{1 / 2}$ for the copigment BM sample increased by $2.23 \%$ at $70^{\circ} \mathrm{C}$, $5.49 \%$ at $80{ }^{\circ} \mathrm{C}, 2.51 \%$ at $90{ }^{\circ} \mathrm{C}$, and $22.63 \%$ at $100{ }^{\circ} \mathrm{C}$ compared to the control BM sample. Thus, the effect of copigment was more evident at high temperatures for both $\mathrm{BE}$ and $\mathrm{BM}$.

This behavior can be explained using intermolecular interactions that are present between the copigment phytic acid and the flavylium cation of anthocyanins. Some studies emphasize that copigments are rich in pi $(\pi)$ systems and are capable of associating with flavylium ions that provide protection to the anthocyanin molecule (Pedro; Granato; Rosso, 2016; Grajeda-Iglesias et al., 2016).

A copigmentation study on black rice anthocyanins reported $t_{1 / 2}$ as $14.06 \mathrm{~h}$ for control and $15.72 \mathrm{~h}$ for phytic acid copigment in the presence of light. It showed an increase of $11.79 \%$ in half-time life (Pedro; Granato; Rosso, 2016).

Some studies have reported that anthocyanin thermal degradation is due to loss of flavylium cation and hydrolysis of a double bond in the C-ring of the anthocyanin molecule. Application of maltodextrin is a suitable alternative in this degradation process since maltodextrin is a good film-forming, water-based factor and used as a coating molecule for polar solid matrices. This drying aid agent is capable of trapping hydrophilic compounds like anthocyanins by protecting their flavylium cations (Mehran; Masoum; Memarzadeh, 2020; Mahdavi et al., 2016; Burin et al., 2011).

Use of maltodextrin as a drying aid agent provided an increase of $36.39 \%$ in half-time life compared to $\mathrm{BE}$ $(12.42 \mathrm{~h})$ and $\mathrm{BM}(16.94 \mathrm{~h})$, at $70{ }^{\circ} \mathrm{C}$ in the presence of copigment. The increase was $9.36 \%$ at $80{ }^{\circ} \mathrm{C}, 7.40 \%$ at $90{ }^{\circ} \mathrm{C}$, and $5.43 \%$ at $100{ }^{\circ} \mathrm{C}$. The first-order reaction rate constants $(\mathrm{k})$ ranged between $6.82 \times 10^{-4}$ at $70^{\circ} \mathrm{C}$ and 4.95 $\mathrm{x} 10^{-3}$ at $100{ }^{\circ} \mathrm{C}$. A study on anthocyanins degradation from blackberry juice reported $\mathrm{t}_{1 / 2}$ values of $8.8,4.7$, and $2.9 \mathrm{~h}$, and $\mathrm{k}$ values of $1.32 \times 10^{-3}, 2.47 \times 10^{-3}$, and $3.94 \times 10^{-3}$ at temperatures of $70^{\circ} \mathrm{C}, 80^{\circ} \mathrm{C}$, and $90^{\circ} \mathrm{C}$, respectively (Wang; $\mathrm{Xu}, 2007$ ). Our study emphasizes the relevance of the use of maltodextrin to increase the halflife time of blackberry compounds. The compounds could be useful as supplement food ingredients in several types of products. It is important to mention that microsphere could be highly applicable for products that could not tolerate high processing temperatures, and could help to increase the half-life time of anthocyanins and product shelf life.

\section{CONCLUSIONS}

By comparing the microsphere with extract, we found that the microsphere maintained anthocyanin content and increased red color $\left(\mathrm{a}^{*}\right)$ by around $60 \%$, indicating that maltodextrin protects anthocyanin degradation under high temperatures. Moreover, the use of maltodextrin as a drying aid agent provided an increase of $36.39 \%$ in half-life time in the microsphere at $70{ }^{\circ} \mathrm{C}$ in the presence of phytic acid as a copigment. To summarize, blackberry pomace is feasible to use as a functional food because of the bioactive compounds present in it. The high stability of these compounds is appropriate for technological food applications, and the use of blackberry pomace is essential for agribusiness in order to reduce their negative impacts on the environment.

\section{ACKNOWLEDGMENTS}

The authors thank the Coordination for the Improvement of Higher Education Personnel (CAPES) and the National Council for Scientific and Technological Development (CNPq) for the project financing.

\section{REFERENCES}

ALOTHMAN, M.; BHAT, R.; KARIM, A. A. Antioxidant capacity and phenolic content of selected tropical fruits from Malaysia, extracted with different solvents. Food Chemistry, 115:785-788, 2009.

BURIN, V. M. et al. Anthocyanins: Optimisation of extraction from Cabernet Sauvignon grapes, microcapsulation and stability in soft drink. International Journal of Food Science \& Technology, 46(1):186-193, 2011.

CUADROS, J. et al. Color analysis and detection of Fe minerals in multi-mineral mixtures from acid-alteration environments. Applied Clay Science, 193:105677, 2020.

EZHILARASI, P. N. et al. Freeze drying technique for microencapsulation of garcinia fruit extract and its effect on bread quality. Journal of Food Enginnering, 117:513520, 2013.

FERRARI, C. C. et al. Influence of carrier agents on the physicochemical properties of blackberry powder produced by spray drying. International Journal of Food Science and Technology, 47(6):1237-1245, 2012. 
GRAJEDA-IGLESIAS, C. et al. Isolation and characterization of anthocyanins from hibiscus Sabdariffa Flowers. Journal of Natural Products, 79(7):1709-1718, 2016.

KUCK, L. S.; NOREÑA, C. P. Z. Microencapsulation of grape (Vitis labrusca Var. Bordo) skin phenolic extract using gum arabic, polydextrose, and partially hydrolyzed guar gum as encapsulating agents. Food Chemistry, 194:569-576, 2016.

LEE, J.; DURST, R. W.; WROLSTAD, R. E. Determination of total monomeric anthocyanin pigment content of fruit juices, beverages, natural colorants, and wines by the $\mathrm{PH}$ differential method: Collaborative study. Journal of AOAC International, 88(5):1269-1278, 2005.

LISBOA, H. M.; DUARTE, M. E.; CAVALCANTI-MATA, M. E. Modeling of food drying processes in industrial spray dryers. Food and Bioproducts Processing, 107:49-60, 2018.

MACHADO, A. P. F. et al. Encapsulation of anthocyanin-rich extract from blackberry residues by spray-drying, freezedrying and supercritical antisolvent. Powder Technology, 340:553-562, 2018.

MACIEL, L. G. et al. Hibiscus sabdariffa anthocyanins-rich extract: Chemical stability, in vitro antioxidant and antiproliferative activities. Food and Chemical Toxicology, 113:187-197, 2018.

MAHDAVI, S. A. et al. Microencapsulation optimization of natural anthocyanins with maltodextrin, gum arabic and gelatin. International Journal of Biological Macromolecules, 85:379-385, 2016.

MEDINA-TORRES, L. et al. Microencapsulation by spray drying of laurel infusions (Litsea glaucescens) with maltodextrin. Industrial Crops and Products, 90:1-8, 2016.

MEHRAN, M.; MASOUM, S.; MEMARZADEH, M. Improvement of thermal stability and antioxidant activity of anthocyanins of Echium amoenum petal using maltodextrin/modified starch combination as wall material. International Journal of Biological Macromolecules, 148:768-776, 2020.

MURADOR, D. et al. Alterations in phenolic compound levels and antioxidant activity in response to cooking technique effects: A meta-analytic investigation. Critical Reviews in Food Science and Nutrition, 58(2):169177, 2018.

NENADIS, N. et al. Estimation of scavenging activity of phenolic compounds using the ABTS+ assay. Journal of Agricultural and Food Chemistry, 52:4669-4674, 2004.
PEDRO, A. C.; GRANATO, D.; ROSSO, N. D. Extraction of anthocyanins and polyphenols from black rice (Oryza sativa L.) by modeling and assessing their reversibility and stability. Food Chemistry, 191:12-20, 2016.

PIERPOINT, W. S. The extraction of enzymes from plant tissues rich in phenolic compounds. Methods in Molecular Biology, 244:65-74, 2004.

PITALUA, E. et al. Antioxidative activity of microcapsules with beetroot juice using gum arabic as wall material. Food and Bioproducts Processing, 88(2-3):253-258, 2010.

PULIDO, R.; BRAVO, L.; SAURA-CALIXTO, F. Antioxidant activity of dietary polyphenols as determined by a modified ferric reducing/ antioxidant power assay. Journal of Agricultural and Food Chemistry, 48:3396-3402, 2000.

RAMOS, F. M. et al. Drying of maltodextrin solution in a vaccum spray dryer. Chemical Engineering Research and Design, 146:78-86, 2019.

REYES, L. F.; CISNEROS-ZEVALLOS, L. Degradation kinetics and colour of anthocyanins in aqueous extractsof purpleand red-flesh potatoes (Solanum tuberosum L.). Food Chemistry, 100:885-894, 2007

REZENDE, Y. R. R. S.; NOGUEIRA, J. P.; NARAIN, N. Microencapsulation of extracts of bioactive compounds obtained from acerola (Malpighia emarginata DC) pulp and residue by spray and freeze drying: Chemical, morphological and chemometric characterization. Food Chemistry, 254:281-291, 2018.

RODRIGUES, L. M. et al. Microcapsules of 'Jabuticaba' byproduct: Storage stability and application in gelatin. Revista Brasileira de Engenharia Agrícola e Ambiental, 22(6):424-429, 2018.

SALMINEN, $\mathrm{H}$. et al. Influence of spray drying on the stability of food-grade solid lipid nanoparticles. Food Research International, 119:741-50, 2019.

SANTOS, S. S. et al. Microencapsulation of bioactive compounds from blackberry pomace (Rubus fruticosus) by spray drying technique. International Journal of Food Engineering, 13(9):20170047, 2017a.

SANTOS, S. S. et al. Microcapsules of blackberry pomace (Rubus fruticosus): Light and temperature stability. Chemical Engineering Transactions, 57:1837-1842, 2017b.

SANTOS, S. S. et al. Antioxidant compounds from blackberry (Rubus fruticosus) pomace: Microencapsulation by spraydryer and ph stability evaluation. Food Packaging and Shelf Life, 20:100177, 2019. 
SINELA, A. et al. Anthocyanins degradation during storage of Hibiscus sabdariffa extract and evolution of its degradation products. Food Chemistry, 214:234-241, 2017.

THAIPONG, K. et al. Comparison of ABTS, DPPH, FRAP, and ORAC assays for estimating antioxidant activity from guava fruit extracts. Journal of Food Composition and Analysis, 19:669-675, 2006.
WANG, W. D.; XU, S. Y. Degradation kinetics of anthocyanins in blackberry juice and concentrate. Journal of Food Engineering, 82(3):271-275, 2007.

YE, Q.; GEORGES, N.; SELOMULYA, C. Microencapsulation of active ingredients in functional foods: From research stage to commercial food products. Trends in Food Science \& Technology, 78:167-179, 2018. 